\title{
Financial Development, the Structure of Capital Markets, and the Global Digital Divide
}

Charles Amo Yartey 



\title{
IMF Working Paper
}

Research Department

Financial Development, the Structure of Capital Markets, and the Global Digital Divide

Prepared by Charles Amo Yartey ${ }^{1}$

Authorized for distribution by Eswar Prasad

November 2006

\begin{abstract}
This Working Paper should not be reported as representing the views of the IMF. The views expressed in this Working Paper are those of the author(s) and do not necessarily represent those of the IMF or IMF policy. Working Papers describe research in progress by the author(s) and are published to elicit comments and to further debate.
\end{abstract}

This paper examines the role of financial development and financial structure in explaining cross-country diffusion of information communication technology (ICT). Using panel data for 76 emerging and advanced countries for the period 1990-2003, the paper finds that credit and stock market development tends to foster ICT development. Financial structure, however, does not appear to have any significant relationship with ICT development. The conclusions of the paper highlight the role of financial development in the market for knowledge-based products, and are consistent with theoretical predictions. The finding that financial development is an important determinant of ICT development implies that countries with underdeveloped financial markets may continue to lag behind in the use of ICT.

JEL Classification Numbers: G23, G32

Keywords: ICT, digital divide, financial development, financial structure

Author’s E-Mail Address: cyartey@imf.org

\footnotetext{
${ }^{1}$ I would like to thank colleagues in the Financial Studies Division, Research Department, especially Eswar Prasad, Giovanni Dell’ Ariccia, Luc Laeven, Marco Terrones, and Kenichi Ueda, for useful comments and suggestions. The usual caveat for responsibility still applies.
} 


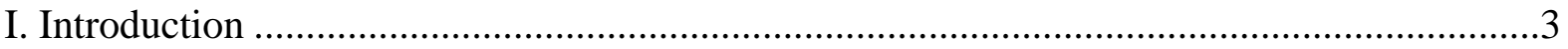

II. Finance, Financial Structure, and Technological Development …...............................4

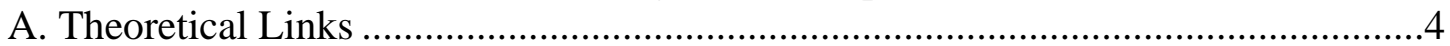

B. Stock Markets and Technological Development ..................................................5

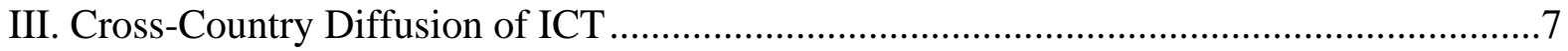

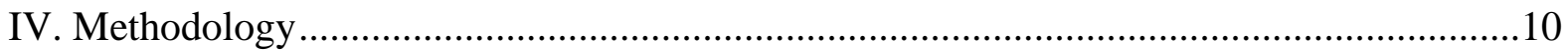

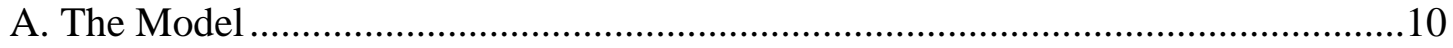

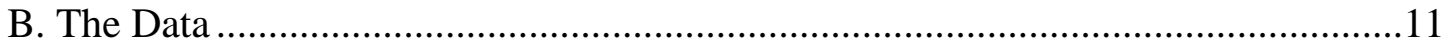

Dependent Variable ................................................................................... 11

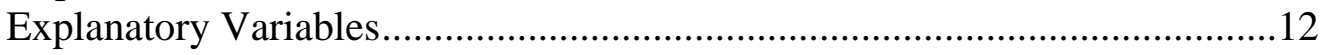

Economic and Infrastructural Factors ....................................................12

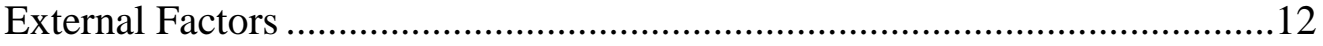

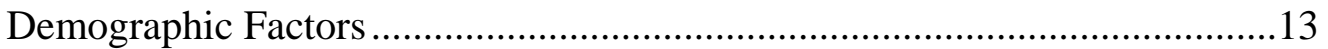

Financial Development and Financial Structure.......................................13

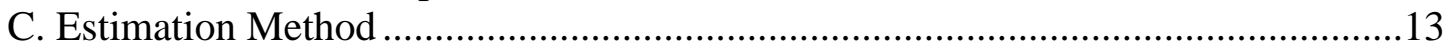

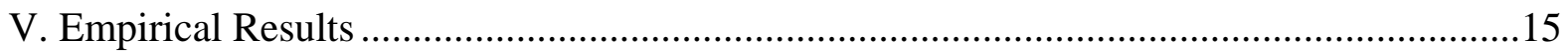

A. Robustness —Financial Structure and ICT in Advanced Countries.......................23

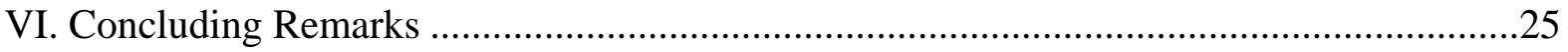

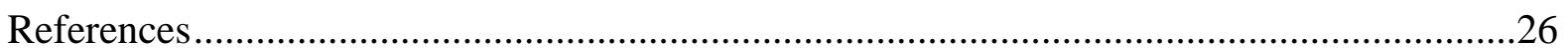

Tables

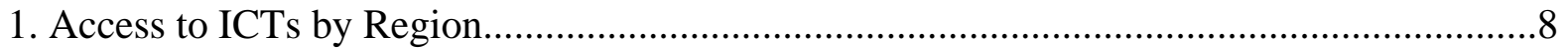

2. ICT Diffusion in Selected Countries (2003) ....................................................................

3. Summary Statistics on Measures of ICT Development ...................................................15

4. Financial Development, Financial Structure, and ICT: GMM Estimation 1.....................16

5. Financial Development, Financial Structure, and ICT: GMM Estimation 2 .....................18

6. Financial Development, Financial Structure, and ICT: GMM Estimation 3....................20

7. Financial Development, Financial Structure, and ICT: GMM Estimation 4....................22

8. Financial Structure and ICT in Advanced Countries: GMM Estimation ..........................24

Figures

1. Number of Countries Connected to the Internet .............................................................. 


\section{INTRODUCTION}

The global economy has been driven by a greater integration of world markets and a spectacular growth of information and communication technologies (ICTs). Recent events, including the acceleration of productivity growth in the United States since 1995, have served to increase interest in this area, since the acceleration appears to be connected with greater investment in ICTs (Chinn and Fairlie, 2004). Interest in the global diffusion of technology has also been increased by the assertion that ICT may improve knowledge diffusion through improving communication efficiency and even allow developing countries to leapfrog traditional methods of increasing productivity (Steinmueller, 2001).

In this paper, we seek to expand the current stock of knowledge on the determinants of ICT development. In particular, we examine the role of financial development and financial structure in explaining cross-country diffusion of ICT. Using panel data for 76 emerging and advanced countries for the period 1990-2003, the paper addresses two main questions:

1. What is the role of financial development and financial structure in explaining crosscountry diffusion of ICT?

2. What kind of financial system or capital market organizations are most conducive to fostering ICT and its use in the economy?

Recent empirical research has documented that technological diffusion in most countries has been hampered by the limited capacity of the network to carry the largest amount of knowledge products in the shortest possible time and by the access of individuals to the network, in which knowledge products are immaterial. In this regard, the development of financial markets may affect both ICT diffusion and its impact on economic growth. In particular, well-developed financial markets can make it easier to finance ICT projects.

The role of finance in promoting technological development has long been a controversial issue. Hicks (1969) argued on the basis of economic history that the British industrial revolution was made possible by the availability of finance. He argued that the large-scale capital requirements of the industrial revolution could only be met by the development of capital market institutions that permitted the pooling of small individual savings into large funds for industrial development. Joan Robinson (1952), on the other hand, saw finance as responding passively to technological innovation and development, and that "where enterprise leads finance follows" (p. 123).

This debate has taken a new turn with the emphasis now being placed on the importance of financial structure for technological development. This new paradigm has been motivated by the apparent emergence of technology companies in the market-based financial system of the 
United States. ${ }^{2}$ The United States has not only experienced fast growth of ICT industries but has also witnessed widespread successful adoption of ICTs in many areas of the economy (Singh, Singh, and Weise, 2001). It is has been suggested that a major reason for the U.S. lead in ICT, and the Japanese and European lag, has been the encouraging role of the stock market. Recent theoretical literature based on endogenous growth models emphasizes the capacity of the stock market to promote innovation and technical progress. This is done practically by devices such as venture capital funds. More specifically, the stock market provides a mechanism whereby market participants utilize their collective knowledge to assess competing new technological inventions. The market is, therefore, better able to finance the most promising technologies compared with banks that do not have the collective wisdom of numerous participants. ${ }^{3}$

There are some previous works that have examined the nature and determinants of the global digital divide (for example, Dasgupta and others, 2001; Kiiski and Pohjola, 2001; Chinn and Fairlie, 2004; and Devan, Ganley, and Kraemer, 2004). However, none of these has made any serious efforts at understanding the role of finance in explaining cross-country diffusion of ICT. We specifically align our work with previous efforts and focus on expanding the results to make several important contributions. Whereas many studies are limited to one or two ICT indicators (most typically, personal computers and the Internet) over a relatively short period, our analysis covers four ICT indicators over a comparatively long period of 1990 to 2003. Further, we conduct our empirical analysis in a panel data framework and using techniques in dynamic panel data analysis. The remainder of the paper is organized as follows. The next section discusses the role of financial development and financial structure in technological development. Section III discusses the growth of ICT and documents cross-country differences in ICT development. Section IV discusses the methodology of the paper. Section V presents the panel regression results. Section VI concludes the paper.

\section{Finance, Financial Structure, AND Technological DeVElopMEnt}

\section{A. Theoretical Links}

The connection between finance and the real sector is well established, at least after the pioneering work of Goldsmith (1969). The link usually emphasized is the role of financial markets in channeling savings toward investment and, more recently, the fact that financial intermediaries are able to solve informational problems that would otherwise lead to inefficient

\footnotetext{
${ }^{2}$ The United States, for instance, has many banks that are small relative to large corporations and play a limited role in corporate governance, and a well-developed stock market with an associated market for corporate control. In contrast, Germany and Japan have fewer banks in number but larger in relative size and are said to play a central governance role.

${ }^{3}$ It is important to emphasize that even though the United States is apparently the leader in information technology, remarkable progress has been made by other industrial and developing countries whose capital markets are very different from that of the United States.
} 
outcomes. Saint-Paul (1992) stressed another link, namely the impact of financial development on technological choice. In Saint-Paul's model, the interactions between technological choice and financial markets create an externality that can lead to multiple equilibria. The intuition is that if financial markets are underdeveloped, then people will choose poorly productive, but flexible technologies. Given these technologies, producers do not experience much risk; hence there is very little incentive to develop financial markets. Conversely, if financial markets are developed, technology will be more specialized and risky, thereby creating the need for financial markets. Thus, there is a strategic complementarity between financial markets and technology, because both are instruments that can be used for diversification.

Allen and Gale (1999b) developed a model to address the normative issue of whether financial markets or intermediaries such as banks are better at providing finance for projects where there is diversity of opinion, such as in the development of new technologies. When a new industry starts up, there are several types of uncertainty. In addition to uncertainty about the effectiveness of the technology, there is uncertainty about the best management strategies to follow and the effects of each strategy. A large number of people participate directly in the investment decision in market-based systems. This is costly because each investor has to acquire the information to make the decision, but it has a great advantage that each investor makes his own decision based on his own information and his own prior assumptions. This ability to agree to disagree allows innovative projects to be financed.

The nature of intermediated finance is different. The decision to invest in a new technology is delegated to a manager. Funds can be allocated to a project even if some of the investors providing the funds think the project is a bad one. The advantage of the intermediary is that it economizes on the acquisition of information, because only the manager needs to become informed. This is fine when investors have homogeneous beliefs. The problem arises when there is a diversity of opinion. Even if the manager does his/her best to choose projects he/she honestly believes are profitable, diversity of opinion implies that some providers of finance would disagree with those decisions even if they had the same information as the manager. If the probability of disagreement is sufficiently high, investors may be unwilling to provide funds in the first place. Thus, intermediated finance may result in underfunding of innovative projects. The model suggests that market-based systems will probably lead to more innovation than bankbased systems.

\section{B. Stock Markets and Technological Development}

Stock-market-based systems are regarded as particularly conducive to innovation, specifically in relation to ICT. Lawrence Summers, the former U.S. Treasury Secretary, for instance, argued that the U.S. financial markets have played a great role in making resources for people who can raise a million dollars before they can buy their first suit. The huge investments in new technology firms in the United States., in spite of their zero or negative profits, is an obvious refutation of the short-termism of the stock market. 
Advocates of stock-market-based systems stress the adaptive features of the market for corporate control that are lacking in bank-centered systems, and the lack of empirical evidence of short-termism (Gilson, 1996). The takeover mechanism, which allows for hostile acquisitions, is regarded as being particularly helpful in the selection process, i.e. in being able to discriminate between useful technologies that benefit society as a whole by increasing shareholder value and those that do not. Thus, a free market for corporate control, by providing financial discipline, is expected to provide the best guarantee of efficiency in the use of assets (George and others, 1991). Similarly, the ability to effect changes in the management of quoted companies is expected to ensure that managerial resources are used efficiently.

Another feature of market-based systems that makes them highly suitable for information technology is the system of incentives, rewards, and punishment. It is suggested that the stockmarket-based system has enabled the widespread use of stock options as a means of payment to those who work for new technology companies. This has helped to align the interest of employees with those of shareholders, leading both to greater social efficiency and greater reward for innovations. The latter derives, in part, from the existence of an exit mechanism, which the U.S. financial system provides in the form of initial public offerings and takeovers. Both these avenues are thought to improve enormously the rewards for innovation compared with bank-based systems, which do not have such mechanisms (Black and Gilson, 1998).

Critics argue that the actual operation of the pricing and takeover mechanism leads to shorttermism a and lower rate of long-term investment, particularly in firm-specific human capital (Singh, 1997). This is because prices react very quickly to a variety of information influencing expectations on financial markets. Therefore, prices on the stock market tend to be highly volatile and enable profits within short periods. In addition, because the stock market undervalues long-term investment, managers are not encouraged to undertake long-term investments since their activities are judged by the performance of a company's financial assets, which may harm long-run prospects of companies (Binswanger, 1999).

In sum, the theoretical case for a stock market economy as being particularly conducive to fostering technical change is far from being unequivocal. The analysis and evidence reviewed above suggests that the stock-market-based financial system has both positive and negative features in relation to promoting technological change. ${ }^{4}$

\footnotetext{
${ }^{4}$ Even though there are many aspects of technology, this paper focuses on information communication technology. It examines the role of financial development and financial structure in explaining crosscountry diffusion of ICT.
} 


\section{Cross-Country Diffusion OF ICT}

The status of ICT adoption in an economy is an indicator of its potential ability to exploit the economic opportunities offered by the new technologies or, more generally, its prospects for transition to the new economy. Access to ICTs has been growing at high speeds, exceeding global economic growth. The growth of mobile phones has been very phenomenal. Since 2002, there are more mobile than fixed telephone subscribers around the world. From just 11 million subscribers in 1990, the number of mobile phone subscribers exceeded 1.4 billion by the end of 2003, experiencing an annual growth rate of 45 percent compared with just 6 percent for fixed telephone line subscribers. In terms of users, about 20 percent of the world's population have mobile phones compared with 0.3 percent in 1991.

The Internet use has also spread at phenomenal speed. From only 20 countries online in 1990, virtually every country in the world has an Internet connection today. By the end of 2003, there were an estimated 691 million Internet users around the world, representing about 11 percent of the global population (Figure 1). In terms of personal computers, the estimated number of personal computers rose from about 120 million in 1990 to 650 million in 2003. Worldwide penetration (personal computers per 100 people) stood at 10.1 at the end of 2003 (International Telecommunication Union, 2005).

Figure 1. Number of Countries Connected to the Internet

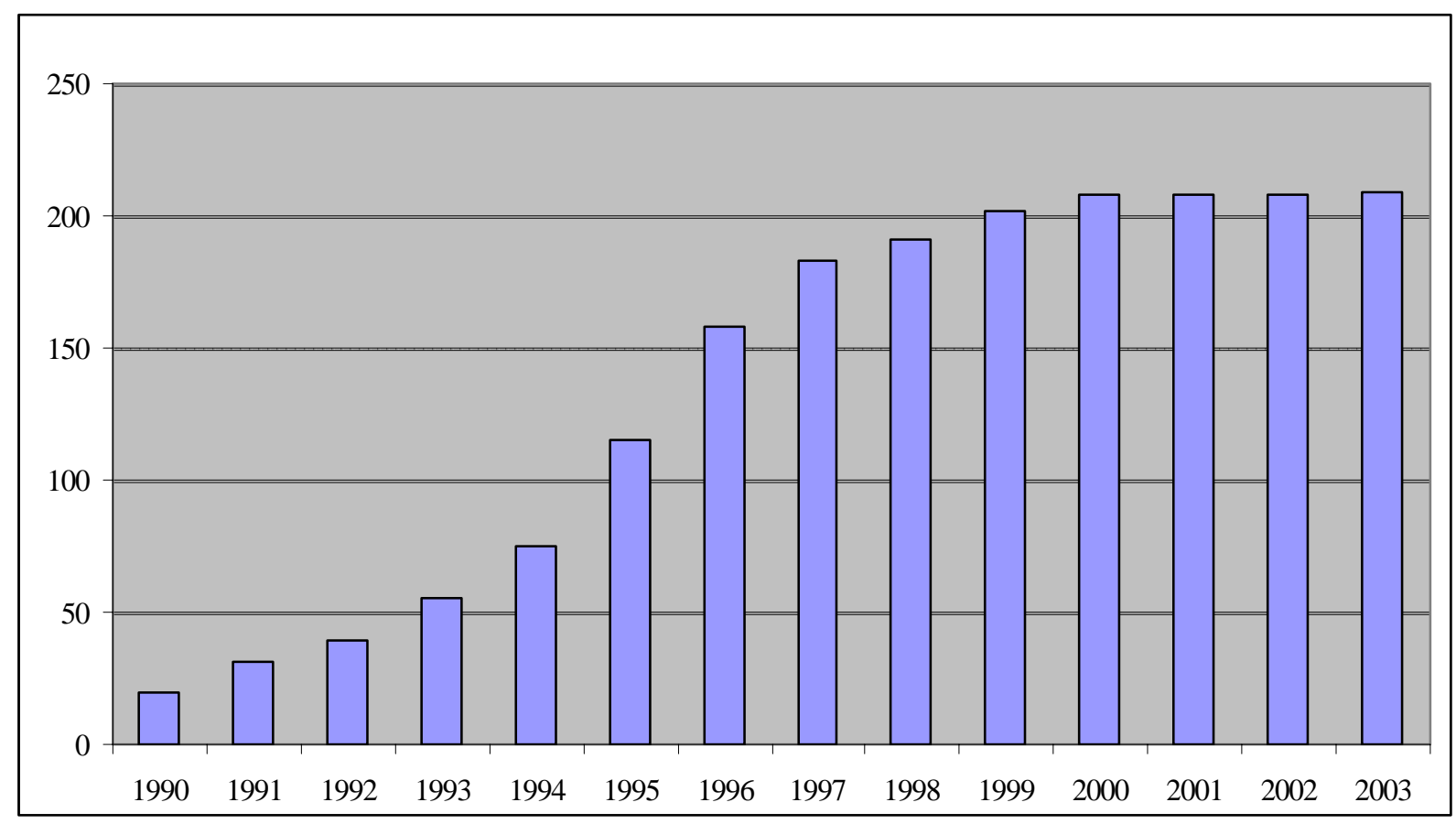

Source: International Telecommunication Union (2005). 
The growth of ICTs has been greatest in the developing world over the past 15 years, moderating somewhat the overall gap between developed and developing countries. In 1992, for example, there were only 3 percent of the world's Internet users from developing countries. Today there are nearly about 40 percent. This trend is true for fixed and mobile phones and the Internet, and occurs despite the increase in population growth in developing countries.

Despite the impressive growth in ICT in recent years, the digital divide has not been erased and continues to separate the information-poor from the information-rich. While at the end of 2003 the developing world made up 85 percent of the world population, it hosted just 55 percent of the world's fixed lines, 53 percent of the world's mobile subscribers, and 39 percent of its Internet users. By the end of 2003, the Internet penetration rate of the developed world was still eight times that of the developing world (International Telecommunication Union, 2005).

The world is also divided by major regional differences in ICT access and use. While almost half of the population in many advanced countries use the Internet, only 1 percent of the population of sub-Saharan Africa were online at the end of 2003 (Table 1). In terms of mobile phone usage, a number of countries such as Luxembourg and Italy had more mobile subscribers than the population, but others like the Democratic Republic of the Congo, Ethiopia, and Lao PDR had penetration rates of less than 3 percent. Even in advanced countries, considerable differences remain in terms of ICT usage across countries. While in 2003 Denmark had 512 Internet users per 1,000 people, Spain only had 239 (Table 2).

Table 1. Access to ICTs by Region

\begin{tabular}{|c|c|c|c|c|c|c|}
\hline & \multicolumn{2}{|c|}{ Telephones lines } & \multicolumn{2}{|c|}{ Personal computers } & \multicolumn{2}{|c|}{ Internet users } \\
\hline & 1990 & 2003 & 1990 & 2003 & 1990 & 2003 \\
\hline World & 10.1 & 40.5 & 2.5 & 10.1 & 0.05 & 11.1 \\
\hline Developed & 45.4 & 124.7 & 11.1 & 44.9 & 0.3 & 44.8 \\
\hline CIS & 12.0 & 29.4 & 0.3 & 6.8 & 0.0 & 3.6 \\
\hline $\begin{array}{l}\text { Transition economies- } \\
\text { Europe }\end{array}$ & 13.8 & 57.7 & 0.2 & 6.5 & 0.0 & 13.5 \\
\hline Developing & 2.3 & 25.0 & 0.3 & 3.4 & 0.0 & 5.1 \\
\hline Northern Africa & 2.9 & 21.0 & 0.1 & 2.0 & 0.0 & 3.4 \\
\hline Sub-Saharan Africa & 1.0 & 6.0 & 0.3 & 1.2 & 0.0 & 1.1 \\
\hline $\begin{array}{l}\text { Latin America and } \\
\text { Caribbean }\end{array}$ & 6.4 & 40.4 & 0.6 & 6.8 & 0.0 & 9.0 \\
\hline Eastern Asia & 2.4 & 47.3 & 0.3 & 5.6 & 0.0 & 8.9 \\
\hline South Asia & 0.7 & 7.1 & 0.0 & 1.1 & 0.0 & 1.7 \\
\hline South Eastern Asia & 1.4 & 20.9 & 0.3 & 2.8 & 0.0 & 6.1 \\
\hline Western Asia & 10.0 & 45.8 & 1.2 & 5.6 & 0.0 & 7.2 \\
\hline Oceania & 3.4 & 10.1 & 0.0 & 6.1 & 0.0 & 3.8 \\
\hline
\end{tabular}

Source: International Telecommunications Union (2005) 
Table 2. ICT Diffusion in Selected Countries (2003)

\begin{tabular}{llll}
\hline Country & $\begin{array}{l}\text { Computers per } \\
1,000 \text { People }\end{array}$ & $\begin{array}{l}\text { Internet Users per 1,000 } \\
\text { People }\end{array}$ & Population \\
& & & \\
\hline Developed Countries & & & \\
Switzerland & 708.66 & 351.04 & $7,290,000$ \\
United States & 658.88 & 551.38 & $288,000,000$ \\
Singapore & 622.04 & 504.36 & $4,164,000$ \\
Sweden & 621.27 & 573.07 & $8,924,000$ \\
Denmark & 576.82 & 512.82 & $5,374,300$ \\
Australia & 565.10 & 566.66 & $19,881,000$ \\
Norway & 528.31 & 307.23 & $4,538,000$ \\
Canada/1 & 487.04 & 512.83 & $31,630,000$ \\
Netherlands & 466.63 & 506.33 & $16,144,000$ \\
United Kingdom & 405.70 & 423.10 & $59,229,000$ \\
Japan & 382.16 & 448.86 & $127,000,000$ \\
& & & \\
Developing Countries & & & \\
Korea & 555.84 & 515.56 & $47,640,000$ \\
Mexico & 81.99 & 98.48 & $101,000,000$ \\
Brazil/1 & 74.77 & 82.24 & $177,000,000$ \\
South Africa & 72.60 & 68.20 & $45,345,287$ \\
Zimbabwe & 51.57 & 42.98 & $13,000,965$ \\
China & 27.64 & 46.01 & $1,280,000,000$ \\
Russia & 19.74 & 63.29 & $146,000,000$ \\
Indonesia & 11.88 & 21.22 & $212,000,000$ \\
Bangladesh & 7.77 & 1.80 & $138,000,000$ \\
India & 7.20 & 15.91 & $1,050,000,000$ \\
Nigeria & 7.10 & 3.50 & $133,000,000$ \\
Pakistan & 4.21 & 10.28 & $141,000,000$ \\
& & & \\
\hline Source Won & & \\
\hline
\end{tabular}

Source: World Development Indicators (2005)

$1 / 2002$ values.

A comparison of Internet penetration rates reveals similar regional patterns. In North America, roughly one-half of the population uses the Internet. In contrast, slightly more than $1 / 2$ of 1 percent of the population uses the Internet in South Asia and sub-Saharan Africa. Examining computer penetration across countries also reveals interesting patterns. According to the data, Switzerland has the highest computer penetration rate. The top ten also include a number of European countries and Canada. All of these countries have very high per capita income.

These trends show that even though disparities have been generally decreasing over the past decade, particularly in terms of access to mobile phones and the Internet, there are still major gaps among economies today. In many parts of the world, the arrival of the information economy and society is still a long distance away, and many barriers remain to be identified and eradicated. This paper attempts to identify the underlying factors contributing to the global 
digital divide. In particular, we examine whether, and to what extent, financial development and financial structure can explain cross-country diffusion of ICT.

A number of studies have attempted to estimate the nature and determinants of the global digital divide. The largest portion of research takes a technological perspective, which emphasizes access to fundamental information technologies (usually telephone and Internet access). Wong (2002) evaluates the digital divide in Asian countries based on penetration levels of telephone mainlines, personal computers, and Internet use. Analyzing comparisons of the scale of ICT adoption relative to national income, he finds that the digital divide in Asia is wide and has the potential to become more severe.

Bellock and Dimitrova (2003) examine the impact of income, the level of civil liberties, infrastructure, and regional variables on Internet use in a sample of 105 countries. They find that income level is by far the most important determinant, that the relationship appears to be nonlinear, and that increasing civil liberties have a positive and significant impact even in the presence of infrastructure advantages. Using a diffusion model and with the same dependent variable as Bellock and Dimitrova (2003), Kiiski and Pohjola (2001) examined data from 60 countries over the period 1995-2000. They used a Gompetz model of technology diffusion, with explanatory variables such as income per capita, telephone access costs, and the average years of schooling. Their results show that GDP per capita and Internet access cost are important factors in OECD countries, but education is not. However, when developing countries are included in the sample, education becomes significant.

For a cross section of 179 countries, Norris (2000) regressed the number of people online in spring 2000 on a number of variables measuring economic, social, and political development. Besides regional dummies, only GDP per capita and the share of research and development spending in GNP turned out to be statistically significant. Adult literacy, secondary education, and the level of democratization had no explanatory power. In effect, economic factors outweighed all others in predicting cross-country differences in access to the Internet. Regional dummies for the Nordic countries, North America, and Western Europe were also significant, which Norris takes to suggest that there are social and cultural factors that are not being picked up in the model.

\section{Methodology}

\section{A. The Model}

We test the role of financial development and financial structure in explaining cross-country diffusion of ICT using a modified version of the Gompertz technology diffusion model first introduced by Chow (1983). Let $\eta_{i t}$ denote ICT use per 1,000 people in country $i$ in year $t$ and $\eta_{i}^{*}$ be its post-diffusion equilibrium level. Most models of technology adoption assume that over time $\eta_{i t}$ tends to $\eta_{i}^{*}$ along an S-shaped path. 
The Gompertz model of technology diffusion specifies the rate of change in technological adoption as:

$$
\log \eta_{i t}-\log \eta_{i t-1}=\theta_{i}\left[\log \eta_{i}^{*}-\log \eta_{i t-1}\right],
$$

where $\theta$ is the speed of adjustment.

The equilibrium level of technological adoption will be a function of at least the basic demandside variables such as income level. Given that income changes over time, we may argue that $X$ is time dependent and express it as:

$$
\log \eta_{i t}^{*}=\alpha_{i}+\beta_{i} \log X_{i t} .
$$

Substituting and adding a random error term we obtain the following equation:

$$
\log \eta_{i t}-\log \eta_{i t-1}=\theta_{i} \alpha_{i}+\theta_{i} \beta \log X_{i t}-\theta_{i} \log \eta_{i t-1}+\varepsilon_{i t} .
$$

Including measures of financial development and financial structure and other control variables, we specify the following ICT model:

$$
\log \eta_{i t}-\log \eta_{i t-1}=\theta_{i} \alpha_{i}+\theta_{i} \beta \log X_{i t}+\theta_{i} \delta \text { Fin }_{i t}-\theta_{i} \log \eta_{i t-1}+\varepsilon_{i t},
$$

where is $\eta$ a measure of ICT development. The $X$ variables are the control variables consisting of income level, electricity consumption, telephone cost, urban population, total population, trade as percentage of GDP, and foreign direct investment (FDI) as a percentage of GDP. FIN is a measure of financial development and financial structure. We expect the coefficient of financial development to be positive and that of financial structure to be negative in the ICT equation. We fit this model to panel data for 76 countries for the period 1990 to 2003.

\section{B. The Data}

\section{Dependent Variable}

The dependent variable is ICT development. The choice of the ICT variables was dictated entirely by the availability of data. We use four measures of ICT development: telephone mainlines per 1,000, number of personal computers per 1,000, Internet users per 1,000, and mobile phones per 1,000. Data on technology and telecommunications are from the World Bank's World Development Indicators. ${ }^{5}$ Computers and Internet penetration rates are derived

\footnotetext{
${ }^{5}$ It is now very difficult to differentiate between communication technology and information technology. For instance, mobile phones are primarily tools of communication. However, with the advent of wireless applications, consumers can access data and information using cellular phones. In like manner, the Internet is mainly an indicator of information technology, yet many Internet users communicate with other users from their personal computers. Therefore, all four information indicators have also become tools of communication.
} 
from the number of personal computers and Internet users per 1,000 people. These measures suffer from two notable weaknesses. First, the number of personal computers may understate the total use of computers in some countries in which mainframe computers are predominant (Wallsten, 2003). Second, the number of Internet users is based on reported estimates of users, derived from reported Internet service provider (ISP) subscriber counts, or calculated by multiplying the number of Internet hosts by an estimated multiplier. Thus, Internet use may be understated, particularly in developing countries, where many commercial subscribers rent computers connected to the Internet. ${ }^{6}$

\section{Explanatory Variables}

Having established a base to evaluate the trends in the global digital divide, we turn to analyze the factors that affect its development. We have selected the most likely candidates for inclusion in our model because of their importance in past results and data availability.

\section{Economic and Infrastructural Factors}

The first category includes GDP per capita and the cost factors that affect technology adoption decisions. Consistent with the evidence suggesting the existence of a digital divide, we would expect a positive relationship between GDP per capita and all the measures of ICT development (see, for instance, Dewan and Kraemer, 2000, and Quilibria and others, 2003). Income is likely to be a key determinant of ICT use. It has a particular effect on consumers' budget constraints, and it may also affect preferences for owning ICTs. The cost variables are proxies for the costs of acquiring and using technology, which in our case is represented by the cost of local calls as in Chinn and Fairlie (2004), which we expect to be negatively associated with ICT penetration. Another important input is power supply. This is proxied by per capita electricity consumption. Unfortunately, we do not have a measure of the proportion of the population with access to electricity. A positive relationship is again expected between electricity consumption and ICT adoption.

\section{External Factors}

The second category of variables captures the external environment and is made up of trade openness and FDI. Trade openness is measured as the sum of the ratio of exports and imports to GDP. It measures how big trade barriers are. Since trade barriers tend to be correlated with other domestic constraints to commerce, trade openness is usually taken to represent the extent of the regulation of the business environment. Both export and imports may offer a channel for

\footnotetext{
${ }^{6}$ Estimates of the number of Internet hosts in a country may also have measurement problems because they are based on country codes and do not necessarily capture the physical location of the host. Furthermore, hosts that do not have a country code are assigned to the United States (Wallsten, 2003).
} 
increased adoption and diffusion of ICT. Inward FDI is usually expected to allow recipient economies access to advanced technologies, managerial skills, and a higher level of technical know-how. Multinational corporations tend to standardize their operations around the world and train workers in host countries according to their skill standards, including the use of ICT. Thus, it is reasonable to expect higher inward FDI to contribute to ICT diffusion.

\section{Demographic Factors}

The third category of variables is demographic, which includes factors that affect the value of access to technology. We control for the proportion of the population residing in urban areas. While the inclusion of this variable is motivated by prior studies (for instance, Forman and others, 2002), its effects on ICT development are ambiguous. On the one hand, the larger the proportion of urban population, the higher the demand for information-intensive products and services, and therefore the stronger the derived demand for ICT. On the other hand, many researchers have argued that the more urban the population, the less pressing the need for ICT to compensate for distance-related communication (Forman, Goldfarb, and Greenstein, 2002). In addition to urban population, we control for the size of the population in all regressions.

\section{Financial Development and Financial Structure}

Broadly speaking, financial structure can be defined as the institutions, financial technology, and the rules of the game that define how financial activities are organized at a particular time period (Stulz, 2001). It is important to distinguish financial structure from financial development. Financial development simply refers to the development of well-functioning financial markets and intermediaries. It consist of both an increased quantity of intermediated savings and an increase in the quality of intermediated services. Financial development depends on the financial structure of the economy and can occur through informal curb markets, rudimentary banks, modern banks, nonbank financial institutions, and through the stock market. In this paper financial development is measured by a number of variables: stock market capitalization as a percentage of GDP (stock market development); credit to the private sector as a percentage of GDP (credit market development); stock market capitalization plus bank assets, all as a percentage of GDP (financial development—size); and stock market value traded plus credit to the private sector, all as a percentage of GDP (financial development-activity). To measure financial structure, we follow the criteria proposed by Demirguc-Kunt and Levine (1999). In particular, we measure financial structure as the ratio of bank assets to stock market capitalization.

\section{Estimation Method}

We estimate the ICT equation with panel data for 76 countries over the period 1990 to 2003. Most explanatory variables in our model are either simultaneously determined with the dependent variable or have a two-way causal relationship with it. There is also the potential of the presence of unobserved country-specific effects. Ignoring them may produce inconsistent 
estimates given that country specific-effects are likely to be correlated with the explanatory variables. In the presence of any correlation between the right-hand-side variables and the country-specific effects, estimation methods such as ordinary least squares (OLS) will not be consistent. This is because of the violation of the assumption of strict exogeneity of the explanatory variables. In addition, the orthogonality condition between the error term and the regressors is not likely to be met for either the generalized least squares (GLS) or the fixed effects estimator to produce consistent estimates. One can achieve the orthogonality condition through appropriate differencing of the data. However, because the equation contains endogenous regressors as well as the effects of lagged endogenous variables, the error term in the differenced equation is correlated with the lagged dependent variable. Therefore, neither the fixed effect nor the GLS estimator will produce consistent estimates under these circumstances.

In this regard, it is appropriate to use an estimation procedure that simultaneously addresses the issues of correlation and endogeneity. Arellano and Bond (1991) have proposed a dynamic panel data estimator based on Generalized Method of Moments (GMM) methodology that optimally exploits the linear moment restrictions implied by the dynamic panel ICT model. The dynamic GMM estimator is an instrumental variable estimator that uses lagged values of all endogenous regressors as well as lagged and current values of all strictly exogenous regressors as instruments. Equations can be estimated using the levels or the first differences of the variables. For the difference estimator, the variables are measured as first differences, and the lagged values of the levels of the variables are used as appropriate instruments.

Arellano and Bond proposed two estimators-one-step and two-step estimators-with the twostep being the optimal estimator. The one- and two-step estimators will be asymptotically equivalent if the error terms are spherical. There is a tendency for the two-step estimator to underestimate the standard errors of estimates, and hence to provide a false sense of precision under some circumstances. The usual practice is to estimate with the two-step estimator but base hypothesis tests on the one-step estimator's statistics. We employ this practice in this paper. However, before proceeding with the GMM the following identifying assumption is necessary. We assume that there is no second-order serial correlation in the first differences of the error term. The consistency of the GMM estimator requires that this condition be satisfied. Given the construction of the instruments as lagged variables, the presence of second-order serial correlation will render such instruments invalid. The specification tests for the GMM estimator are the Sargan test of overidentifying restrictions and the test of lack of residual serial correlation. The Sargan test is based on the sample analog of the moment conditions used in the estimation process and evaluates the validity of the set of instruments and, therefore, determines the validity of the assumptions of predeterminacy, endogeneity, and exogeneity. Since in this case the residuals examined are those of the regressions in differences, first-order serial correlation is expected by construction and thus only second- and higher-order serial correlation is a sign of misspecification. 


\section{EMPIRICAL RESULTS}

The 15 section presents the results of the empirical analysis on the basis of data for a large number of developed and emerging economies. To test the robustness of the model, four equations were estimated. We use the same explanatory variables for each ICT indicator. This is based on the hypothesis that the same factors are likely to influence country-level Internet penetration, personal computer use, and fixed and mobile phone use. In particular, income, FDI, trade, financial development, and financial structure may be relevant determinants of all our ICT indicators.

Summary statistics for the ICT indicators are provided in Table 3. It is clear that the worldwide average penetration levels have grown significantly in all four technologies, especially in the past decade. The penetration rate for personal computers has more than doubled, from an average of 39.61 per thousand in 1990 to 160.62 per thousand in 2003. In like manner, mobile phones have grown rapidly from an average of 5.91 per thousand in 1990 to 506.06 per thousand in 2003.

Table 3. Summary Statistics on Measures of ICT Development

\begin{tabular}{lllllll}
\hline Variables & Year & Mean & $\begin{array}{l}\text { Std. } \\
\text { Deviation }\end{array}$ & Minimum & Maximum & $\begin{array}{l}\text { Number } \\
\text { of Observations }\end{array}$ \\
\hline Computers & 1990 & 39.61 & 47.71 & 0.05 & 217.92 & 52 \\
Mobile phones & 2003 & 160.62 & 181.39 & 7.77 & 557.97 & 13 \\
& 1990 & 5.91 & 12.02 & 0.00 & 53.69 & 75 \\
Internet users & 2003 & 506.06 & 340.55 & 10.10 & 1193.80 & 70 \\
& 1990 & 4.48 & 10.07 & 0.00 & 48.03 & 22 \\
Tel. mainlines & 2003 & 248.52 & 190.11 & 1.80 & 674.74 & 51 \\
& 1990 & 215.92 & 207.14 & 1.96 & 734.51 & 76 \\
& 2003 & 802.67 & 555.43 & 4.84 & 1991.30 & 65 \\
\hline
\end{tabular}

Note: All measures are per 1,000.

The results from the model exploring the relationship between financial development, financial structure, and ICT development are reported in Tables 4 to 7 . Table 4 displays the statistical results from estimating the model with telephone mainlines per 1,000 as the dependent variable. In model 1, we have the baseline model with variables such as lag of telephone mainlines, stock market development, credit market development, FDI, trade openness, telephone cost, electricity consumption, and log of GDP per capita. The results show that the model captures the process of diffusion because the coefficient of the lagged dependent variable is significant. The analysis also shows that both stock market development and credit market development are positively associated with ICT development measured by telephone mainlines per 1000. In particular, a percentage point increase in stock market development increases telephone mainlines by 0.49 percentage points. In like manner, a percentage point increase in credit to the private sector as a percentage of GDP increases telephone mainlines per 1,000 by 0.28 
percentage points. FDI, trade openness, GDP per capita, and lag of telephone mainlines are all significant and positive. The cost of telephone calls has an insignificant negative relationship with the diffusion of telephones. Per capita electricity consumption has a wrong negative sign even though this relationship is statistically insignificant. Population enters with a highly significant negative sign.

Table 4. Financial Development, Financial Structure, and ICT:

GMM Estimation 1

(Dependent variable: Telephone mainlines per 1,000 population)

\begin{tabular}{|c|c|c|c|}
\hline & Model 1 & Model 2 & Model 3 \\
\hline Lagged dependent & $\begin{array}{l}0.8493 \\
(51.87) * * *\end{array}$ & $\begin{array}{l}0.8684 \\
(55.40) * * *\end{array}$ & $\begin{array}{l}0.8364 \\
(49.18) * * *\end{array}$ \\
\hline Foreign direct investment & $\begin{array}{l}2.9193 \\
(7.07) * * *\end{array}$ & $\begin{array}{l}2.7110 \\
(6.08) * * *\end{array}$ & $\begin{array}{l}2.7972 \\
(6.86) * * *\end{array}$ \\
\hline Trade openness & $\begin{array}{l}0.9754 \\
(3.98) * * *\end{array}$ & $\begin{array}{l}1.0106 \\
(3.98) * * *\end{array}$ & $\begin{array}{l}0.9619 \\
(3.59) * * *\end{array}$ \\
\hline Urban population & $\begin{array}{l}-1.8660 \\
(-1.08)\end{array}$ & $\begin{array}{l}-2.4555 \\
(-1.37)\end{array}$ & $\begin{array}{l}-2.6675 \\
(-1.48)\end{array}$ \\
\hline Telephone cost & $\begin{array}{l}1.1277 \\
(0.23)\end{array}$ & $\begin{array}{l}-0.6401 \\
(-0.13)\end{array}$ & $\begin{array}{l}-6.1939 \\
(-1.13)\end{array}$ \\
\hline GDP per capita & 128.4285 & $\begin{array}{l}133.70 \\
(261) * * *\end{array}$ & 102.309 \\
\hline Electricity consumption & $\begin{array}{l}0.5678 \\
(0.02)\end{array}$ & $\begin{array}{l}-8.1533 \\
(-0.21)\end{array}$ & $\begin{array}{l}1.0162 \\
(0.03)\end{array}$ \\
\hline Population & $\begin{array}{l}-50.967 \\
(-5.48) * * *\end{array}$ & $\begin{array}{l}-47.4735 \\
(-5.11) * * *\end{array}$ & $\begin{array}{l}-53.7296 \\
(-5.48) * * *\end{array}$ \\
\hline Time dummies & 14.8005 & 14.1786 & 16.9854 \\
\hline Stock market development & $\begin{array}{l}(7.51) * * * \\
0.4903\end{array}$ & $(7.41) * * *$ & $(8.27) * * *$ \\
\hline Credit market development & $\begin{array}{l}(7.73) * * * \\
0.2814\end{array}$ & & \\
\hline Financial structure & $(1.81) *$ & -1.0347 & 10.7383 \\
\hline Financial development (size) & & $\begin{array}{l}(-0.22) \\
0.4476\end{array}$ & $(2.72) * * *$ \\
\hline Financial development (activity) & & $(6.35) * * *$ & $\begin{array}{l}0.3246 \\
(5.00) * * *\end{array}$ \\
\hline $\begin{array}{l}\text { Number of observations } \\
\text { Sargan test of overidentifying restriction } \\
\text { Test of } 1^{\text {st }} \text { order residual autocorrelation }\end{array}$ & $\begin{array}{l}540 \\
\text { Chi2(65)=398.38 } \\
{[0.0000] * * *} \\
Z=-5,75\end{array}$ & $\begin{array}{l}564 \\
\text { Chi2(65) }=393.48 \\
{[0.0000] * * *} \\
Z=-3.77\end{array}$ & $\begin{array}{l}515 \\
\text { Chi2(65) }=385.90 \\
{[0.0000] * * *} \\
Z=-6.30\end{array}$ \\
\hline $\begin{array}{l}\text { Test of } 2^{\text {nd }} \text { order residual } \\
\text { autocorrelation }\end{array}$ & $\begin{array}{l}{[0.0000] * * *} \\
Z=0.27 \\
{[0.7874]}\end{array}$ & $\begin{array}{l}{[0.0002] * * *} \\
\mathrm{Z}=-0.91 \\
{[0.3641]}\end{array}$ & $\begin{array}{l}{[0.0000] * * *} \\
Z=-1.27 \\
{[0.2041]}\end{array}$ \\
\hline
\end{tabular}

Note: All regressions include time dummies. $T$ values in parenthesis and $p$ values in squared bracket. ***, **, and * implies significant at 1, 5 and 10 percent significant levels respectively. 
In model 2, we examine the impact of financial structure and financial development (overall size) on the diffusion of telephone mainlines. The results show that lag of telephone mainlines, FDI, trade openness, financial development (size) are all significant and positive. In particular, a percentage point increase in financial development increases telephone mainlines per 1,000 by 0.45 percentage points. Financial structure, however, is negative, indicating that economies with a high ratio of banks to stock markets tend to have a lower value for telephone mainlines. However, this relationship is statistically not significant. Urban population has a negative and significant relationship with telephone mainlines development. Per capita electricity consumption has a wrong negative sign but is statistically not significant. Trade openness, FDI, and GDP per capita are all positive and significant. Population is negative and highly significant.

In model 3, we examine the impact of financial development, measured as the sum of credit to the private sector as a percentage of GDP and stock market value traded as a percentage of GDP, on telephone mainlines. Since credit to the private sector represents the extent of the development of the activities of financial intermediaries, and stock market value traded represents the development of stock market activity, this indicator is called financial development (activity). The results show that lag of telephone mainlines, FDI, trade openness, income level, financial development (activity), and financial structure are all positive and significant. For instance, a percentage point increase in the activities of financial intermediaries and stock markets increases ICT development by 0.33 percentage points. In like manner, a percentage point increase in the ratio of bank assets to stock market capitalization increases ICT development by 10.74 percentage points. Population is negative and significant. Urban population enters with an insignificant negative coefficient.

We now take up the results for mobile phone penetration rates. To maximize comparability with the results for telephone mainlines, we retain all of the explanatory variables in our specification. Table 5 presents the estimates using mobile phones as the ICT indicator. In model 1 we have the baseline model with credit to the private sector as a percentage of GDP and stock market capitalization as a percentage of GDP as the indicators of financial development. The empirical results indicate that the model captures the process of diffusion, since the coefficient of the lagged dependent variable is significant. The results also suggest that FDI, trade openness, GDP per capita, and stock market development are all positive and significant. A percentage point increase in stock market development increases ICT diffusion by 0.32 percentage points. Credit market development this time is not significant even though it has the expected positive sign. Telephone cost is also significant with the expected negative sign. Urban population and total population are all negative and significant. Per capita electricity consumption has an insignificant negative sign. 
Table 5. Financial Development, Financial Structure, and ICT:

GMM Estimation 2

(Dependent variable: Mobile phones per 1,000 population)

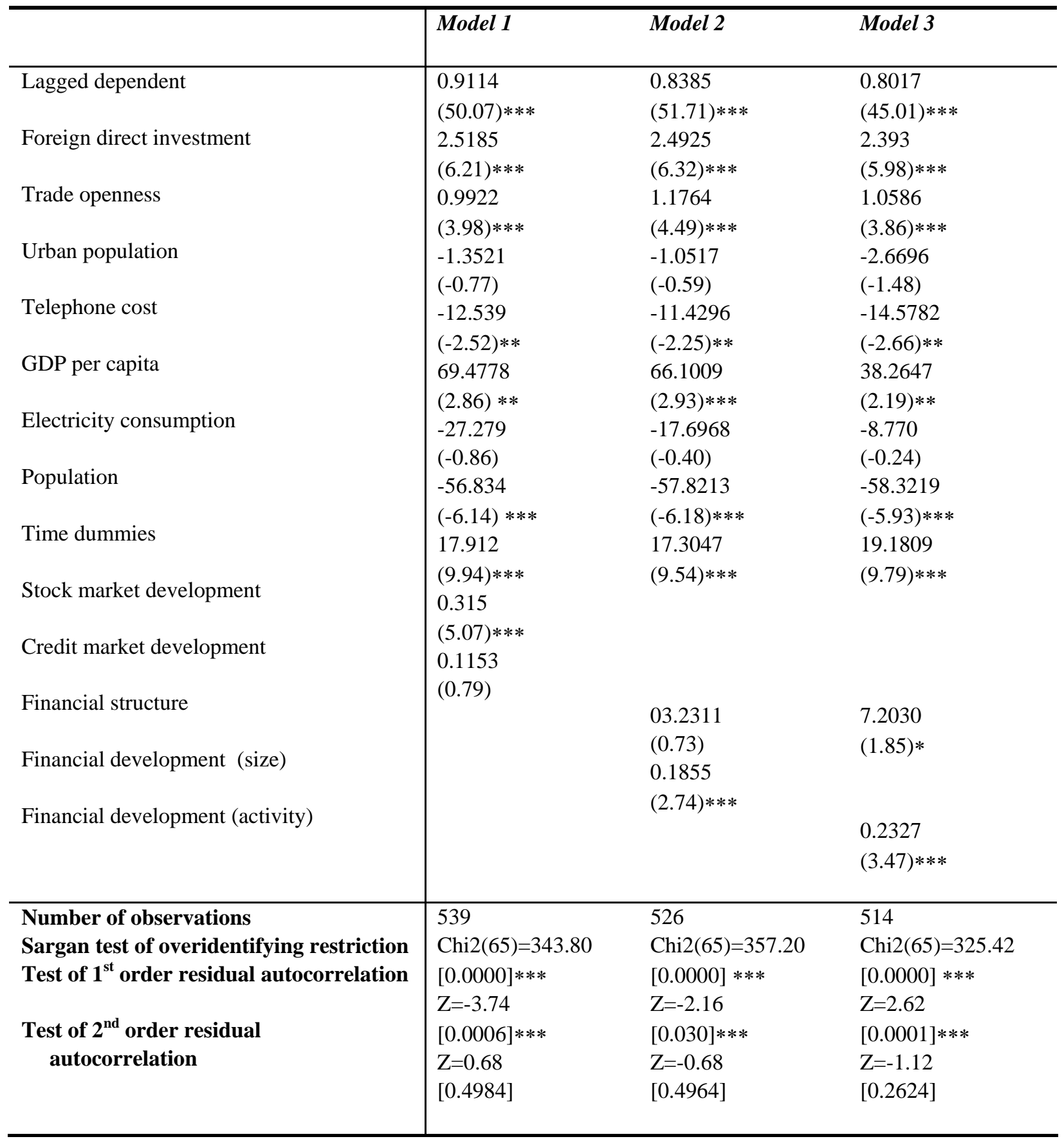

Note: All regressions include time dummies. $T$ values in parenthesis and $p$ values in squared bracket. $* * *, * *$, and $*$ implies significant at 1, 5 and 10 percent significant levels respectively. 
In model 2 we examine the impact of financial structure and financial development on the diffusion of mobile phones. The results show that lag of mobile phones, FDI, trade openness, GDP per capita, and financial development are all positive and statistically significant. In particular, a percentage point increase in financial development increases ICT development by 0.19 percentage points. Financial structure is positive but statistically, insignificant indicating that the structure of a country's financial system does not matter for ICT development. We find that the urban population ratio once again enters as a negative factor, which contrast with the results in a number of other studies. This finding suggests that, after controlling for telephone cost and power supply, mobile phones substitutes for the benefits accruing to operating in an urbanized environment. This result is consistent with the global village theory as opposed to the urban density theory. ${ }^{7}$ Telephone cost and population size are also negative and statistically significant. Electricity consumption again is negative and statistically insignificant.

In model 3, we examine the impact of financial development (activity) on the diffusion of mobile phones. The results suggest that lag of mobile phones, FDI, trade openness, GDP per capita, and financial development are all positive and significant. For example, a percentage point increase in the activities of both banks and stock markets increases ICT development by 0.23 percentage points. Financial structure this time is positive and statistically significant. Population and telephone cost are all negative and significant. Per capita electricity consumption has a wrong negative sign and is not statistically significant.

We next take up the results for Internet users per 1,000 (Table 6). In model 1, we have our baseline model. The empirical results indicate that the model captures the process of diffusion, since the coefficient of the lagged dependent variable is significant. The result also suggests that FDI, trade openness, GDP per capita, stock market development, and credit market development are all significant and positive. In particular, a percentage point increase in stock market development increases Internet usage per 1,000 by 0.20 percentage point. Similarly, a percentage point increase in credit market development increases Internet usage by 0.17 percentage points. Population size is negative and statistically significant. Telephone cost, electricity consumption, and urban population are negative but statistically insignificant.

In model 2, we examine the impact of financial development and financial structure on ICT development measured by Internet usage per 1,000. The empirical evidence suggests that lag of Internet, FDI, trade, GDP per capita, per capita electricity consumption, and financial development (size) are all positive and significant. A percentage point increase in financial development induces a 0.07 percentage increase in ICT development. Financial structure is positive but statistically not significant, implying that the structure of a country's financial system does not matter for ICT development. Total population is negative and statistically

\footnotetext{
${ }^{7}$ See Forman, Goldfarb, and Greenstein (2003) for a discussion of these theories, and the tests of the associated hypotheses using data from the United States.
} 
significant. The negative relationship between population and ICT development is difficult to interpret.

Table 6. Financial Development, Financial Structure, and ICT:

GMM Estimation 3

(Dependent variable: Internet usage per 1,000 population)

\begin{tabular}{|c|c|c|c|}
\hline & Model 1 & Model 2 & Model 3 \\
\hline \multirow[t]{2}{*}{ Lagged dependent } & 0.8630 & 0.9021 & 0.8779 \\
\hline & $(33.98) * * *$ & $(35.40) * * *$ & $(33.47) * * *$ \\
\hline \multirow[t]{2}{*}{ Foreign direct investment } & 1.5311 & 1.5731 & 1.405477 \\
\hline & $(4.86) * * *$ & $(5.15) * * *$ & $(4.90) * * *$ \\
\hline \multirow[t]{2}{*}{ Trade openness } & -0.0709 & 0.0160 & 0.0653 \\
\hline & $(-0.33)$ & $(0.07)$ & $(0.29)$ \\
\hline Urban population & $\begin{array}{l}-0437 \\
(-0.33)\end{array}$ & $\begin{array}{l}0.5211 \\
(0.35)\end{array}$ & $\begin{array}{l}0.0185 \\
(1.4805)\end{array}$ \\
\hline Telephone cost & $\begin{array}{l}-6802 \\
(-0.15)\end{array}$ & $\begin{array}{l}-0.8328 \\
(-0.19)\end{array}$ & $\begin{array}{l}0.1917 \\
(0.04)\end{array}$ \\
\hline GDP per capita & 71.9022 & 85.5124 & 49.2995 \\
\hline Electricity consumption & $\begin{array}{l}(1.74)^{*} \\
-22.829\end{array}$ & -41.268 & 0.0062026 \\
\hline Population & --19.120 & -12.0381 & $\begin{array}{l}(2.35)^{* *} \\
-14.0367\end{array}$ \\
\hline Time dummies & $\begin{array}{l}(-2.09) * * \\
7.8545\end{array}$ & $\begin{array}{l}(-1.38) \\
6.7483\end{array}$ & $\begin{array}{l}(-1.57) * \\
6.8195\end{array}$ \\
\hline Stock market development & $\begin{array}{l}(5.10) * * * \\
0.2014\end{array}$ & $(4.53) * * *$ & $(4.26) * * *$ \\
\hline Credit market development & $\begin{array}{l}(4.12) * * * \\
0.1731\end{array}$ & & \\
\hline Financial structure & $(2.32) * *$ & 8.0620 & 6.6588 \\
\hline Financial development (size) & & $\begin{array}{l}(1.59) * \\
0.0681\end{array}$ & $(1.81) *$ \\
\hline Financial development (activity) & & $(1.60) *$ & $\begin{array}{l}0.2446 \\
(4.51) * * *\end{array}$ \\
\hline \multirow{4}{*}{$\begin{array}{l}\text { Number of observations } \\
\text { Sargan test of overidentifying restriction } \\
\text { Test of } \mathbf{1}^{\text {st }} \text { order residual autocorrelation }\end{array}$} & 455 & 446 & 439 \\
\hline & Chi2(65) $=254.67$ & Chi2(65) $=228.58$ & Chi2(65) $=223.28$ \\
\hline & {$[0.0000] * * *$} & {$[0.0000] * * *$} & {$[0.0000] * * *$} \\
\hline & $\mathrm{Z}=-4.49$ & $\mathrm{Z}=-4.98$ & $\mathrm{Z}=-4.83$ \\
\hline \multirow{3}{*}{$\begin{array}{l}\text { Test of } 2^{\text {nd }} \text { order residual } \\
\quad \text { autocorrelation }\end{array}$} & $[0.0000]] * * *$ & {$[0.0000] * * *$} & {$[0.0000] * * *$} \\
\hline & $\mathrm{Z}=-1.29$ & $\mathrm{Z}=-1.35$ & $Z=-1.58$ \\
\hline & {$[0.1979]$} & {$[0.1763]$} & {$[0.1135]$} \\
\hline
\end{tabular}

Note: All regressions include time dummies. $T$ values in parenthesis and $p$ values in squared bracket. $* * *, * *$, and $*$ implies significant at 1, 5 and 10 percent significant levels respectively. 
In model 3, the indicator of financial development (size) is replaced with an index of financial development (activity). The results show that the lagged dependent variable, FDI, trade openness, and financial development are all positive and statistically significant. In particular, a percentage point increase in the activities of financial intermediaries and banks induces a 0.25 percentage point increase in ICT development. Financial structure is positive and statistically significant. Population size is negative and statistically significant. Urban population is positive but statistically insignificant.

We now turn to the results for computer penetration rates from 1990-2003, which are reported in Table 7. The empirical results indicate that the model captures the process of diffusion, since the coefficient of the lagged dependent variable is significant. The results also suggest that FDI, trade openness, GDP per capita, and stock market development are positive and statistically significant. In particular, a percentage point increase in stock market development increases the computer penetration rate by 0.11 percentage points. Credit market development this time is statistically not significant, even though it has the expected positive sign. Urban population is positive and statistically significant. Population size is negative and significant.

One puzzling result is the insignificance of per capita electricity consumption variable. There is essentially no significant relationship between per capita electricity consumption and computer penetration. This is very surprising since access to electricity is essential for the use of personal computers. One possibility is that there is a threshold effect in the electricity-computer relationship. Widespread availability of a reliable electricity supply is critical to making personal computers economically efficient, and over the range where electrification is occurring, there may be a close link between electricity consumption and use. Once nearly all households have access to electricity, the link between electricity consumption and computer use may break down.

In model 2, we examine the combined impact of stock market development and credit market development on personal computer penetration. The results show that the model captures the process of diffusion, since the coefficient of the lagged dependent variable is significant. The empirical results show that FDI, trade openness, GDP per capita, and financial development are positive and statistically significant. For example, a percentage point increase in financial development increases personal computer penetration by 0.1 percentage points. Financial structure is, however, statistically insignificant, indicating that financial structure has no role in explaining the global computer divide. Urban population is positive, and telephone cost is negative even though they are both statistically not significant. Population size is again negative and significant. 
Table 7. Financial Development, Financial Structure, and ICT:

GMM Estimation 4

(Dependent variable: personal computer usage per 1,000 population)

\begin{tabular}{|c|c|c|c|}
\hline & Model 1 & Model 2 & Model 3 \\
\hline Lagged dependent & $\begin{array}{l}0.9639 \\
(48.78) * * *\end{array}$ & $\begin{array}{l}0.9622 \\
(52.02) * * *\end{array}$ & $\begin{array}{l}0.9436 \\
(48.02) * * *\end{array}$ \\
\hline Foreign direct investment & $\begin{array}{l}0.1545 \\
(1.76) *\end{array}$ & $\begin{array}{l}0.2305 \\
(1.83) *\end{array}$ & $\begin{array}{l}0.2527 \\
(1.74) *\end{array}$ \\
\hline Trade openness & $\begin{array}{l}0.2037 \\
(1.93) *\end{array}$ & $\begin{array}{l}0.1989 \\
(1.82) *\end{array}$ & $\begin{array}{l}0.2342 \\
(2.09) * *\end{array}$ \\
\hline Urban population & $\begin{array}{l}2.0543 \\
(2.89) * *\end{array}$ & $\begin{array}{l}1.8905 \\
(0.57)\end{array}$ & $\begin{array}{l}1.8303 \\
(2.53) * * *\end{array}$ \\
\hline Telephone cost & $\begin{array}{l}-0.0434 \\
(-0.02)\end{array}$ & $\begin{array}{l}-0.1609 \\
(-0.07)\end{array}$ & $\begin{array}{l}0.6132 \\
(0.25)\end{array}$ \\
\hline GDP per capita & 41.1795 & 46.7005 & 32.1268 \\
\hline Electricity consumption & $\begin{array}{l}(2.04) * * \\
-22.9268\end{array}$ & $\begin{array}{l}(2.25) * * \\
35.5396\end{array}$ & $\begin{array}{l}(2.82) * * * \\
-30.956\end{array}$ \\
\hline Population & $\begin{array}{l}(-1.55) \\
-77.5652\end{array}$ & $\begin{array}{l}(2.17) \\
-73.7498\end{array}$ & $\begin{array}{l}(-1.90) * \\
-86.811\end{array}$ \\
\hline Time dummies & $\begin{array}{l}(-1.76) * \\
1.5306\end{array}$ & $\begin{array}{l}(-1.69) * \\
1.6507\end{array}$ & $\begin{array}{l}(-1.86) * \\
2.0182\end{array}$ \\
\hline Stock market development & $\begin{array}{l}(1.77)) * \\
0.1142\end{array}$ & $(1.98) * *$ & $(2.21)) * *$ \\
\hline Credit market development & $\begin{array}{l}(4.34) * * * \\
0.0163 \\
(0.24)\end{array}$ & & \\
\hline $\begin{array}{l}\text { Financial structure } \\
\text { Financial development (size) }\end{array}$ & & $\begin{array}{l}-1.6507 \\
(-1.46) \\
0.1072\end{array}$ & $\begin{array}{l}0.3853 \\
(0.24)\end{array}$ \\
\hline Financial development (activity) & & $(3.73) * *$ & $\begin{array}{l}0.1249 \\
(4.79)) * * *\end{array}$ \\
\hline Number of observations & 507 & 500 & 488 \\
\hline Sargan test of overidentifying restriction & Chi2(65)=253.61 & Chi2(65)=273.99 & Chi2(65)=268.97 \\
\hline Test of $1^{\text {st }}$ order residual autocorrelation & $\begin{array}{l}{[0.0000] * * *} \\
\mathrm{Z}=-7.66\end{array}$ & $\begin{array}{l}{[0.0000] * * *} \\
\mathrm{Z}=-7.51\end{array}$ & $\begin{array}{l}{[0.0000] * * *} \\
\mathrm{Z}=-7.21\end{array}$ \\
\hline $\begin{array}{l}\text { Test of } 2^{\text {nd }} \text { order residual } \\
\text { autocorrelation }\end{array}$ & $\begin{array}{l}[0.0000]] * * * \\
Z=-0.75 \\
{[0.4506]}\end{array}$ & $\begin{array}{l}{[0.0000] * * *} \\
Z=-0.75 \\
{[0.4528]}\end{array}$ & $\begin{array}{l}{[0.0000] * * *} \\
Z=-0.98 \\
{[0.3269]}\end{array}$ \\
\hline
\end{tabular}

Note: All regressions include time dummies. $T$ values in parenthesis and $p$ values in squared bracket. $* * *, * *$, and $*$ implies significant at 1, 5 and 10 percent significant levels respectively. 
In model 3, we examine the effect of the activities of the financial system on ICT development. Financial development is measured using an index of the activities of banks and stock markets. The results shows that lagged personal computers, FDI, trade openness, GDP per capita, and financial development are all positive and statistically significant. A percentage point increase in the activities of financial intermediaries and stock markets increases computer penetration by 0.12 percentage points. Financial structure is positive and statistically significant. Urban population is positive and significant. Electricity consumption has a wrong negative sign and is significant.

In sum, the empirical results provide support for the role of financial development in explaining cross-country diffusion of ICT. Similarly, trade openness,FDI, and GDP per capita are all major determinants of ICT development. This confirms that restrictions to trade and censorship constitute high barriers to the adoption of ICT and its dissemination. Financial structure, however, has no significant role in explaining cross-country diffusion of ICT. It is positive and significant in some specifications of the model.

\section{A. Robustness-Financial Structure and ICT in Advanced Countries}

Our empirical results find no conclusive evidence to support the assertion that stock-marketbased systems are particularly more conducive to innovation, specifically in relation to ICT. This result may be because of the inclusion of developing countries in the sample. We test whether the coefficient of financial structure is statistically the same in and outside of advanced countries. A basic method in applied econometric research is to introduce a dummy variable for advanced countries in the regression and then interact this dummy variable with financial structure to form a new variable (call it advanced structure). The model is then estimated with both the advanced countries dummy and the advanced structure variable in the regression. ${ }^{8} \mathrm{~A}$ $T$-test on the coefficient of advanced structure is then conducted.

The result of this estimation is presented in Table 8. In the second column we have the results of the model with telephone mainlines per 1,000 as the dependent variable. The result shows that the coefficient of financial structure in advanced countries is positive and statistically significant. This result indicates that in advanced countries in which the banking system is relatively more important the stock market tends to have greater use of ICT (measured by telephone mainlines). We also find a similar result when using mobile phones per 1,000 as the dependent variable. In the third column we present the result of the estimation using Internet users per 1,000 as the dependent variable. The result this time shows that advanced structure is not statistically significant even though it has a positive sign. Therefore, we fail to reject the null

\footnotetext{
${ }^{8}$ We include both the advanced dummy and advanced structure in the regression to be sure that any rejection of the null hypothesis would not be due to the fact that the advanced dummy is excluded.
} 
hypothesis that the coefficient of advanced structure in and outside of advanced countries is the same. In the last column, we present the result of the regression using personal computer users as the dependent variable. The result shows that the coefficient of advanced structure is not statistically significant.

Table 8. Financial Structure and ICT in Advanced Countries:

GMM Estimation

\begin{tabular}{|c|c|c|c|c|}
\hline & Dependent Variab & & & \\
\hline & Telephones & Mobile Phones & Internet Users & PC Users \\
\hline Lagged dependent & $\begin{array}{l}0.872 \\
(53.19) * * *\end{array}$ & $\begin{array}{l}0.8381 \\
(48.23) * * *\end{array}$ & $\begin{array}{l}0.8774 \\
(31.28) * * *\end{array}$ & $\begin{array}{l}0.9280 \\
(42.88) * * *\end{array}$ \\
\hline FDI & $\begin{array}{l}2.735 \\
(6.82) * * *\end{array}$ & $\begin{array}{l}2.4554 \\
(6.26) * * *\end{array}$ & $\begin{array}{l}1.5618 \\
(5.15) * * *\end{array}$ & $\begin{array}{l}0.2653 \\
(2.36) * *\end{array}$ \\
\hline Trade openness & $\begin{array}{l}0.976 \\
(3.85) * * *\end{array}$ & $\begin{array}{l}1.1918 \\
(4.57) * * *\end{array}$ & $\begin{array}{l}0.0662 \\
(0.30)\end{array}$ & $\begin{array}{l}0.2558 \\
(0.018) * *\end{array}$ \\
\hline Urban population & $\begin{array}{l}-1.794 \\
(-1.00)\end{array}$ & $\begin{array}{l}-0.1302 \\
(-0.07)\end{array}$ & $\begin{array}{l}0.1092 \\
(0.07)\end{array}$ & $\begin{array}{l}1.5529 \\
(2.13) * *\end{array}$ \\
\hline Population & $\begin{array}{l}-402.47=87 \\
(-4.03) * * *\end{array}$ & $\begin{array}{l}-541.5599 \\
(-5.34) * * *\end{array}$ & $\begin{array}{l}-85.0927 \\
(-0.89)\end{array}$ & $\begin{array}{l}4.4905 \\
(0.10) *\end{array}$ \\
\hline Telephone cost & $\begin{array}{l}1.182 \\
(0.24)\end{array}$ & $\begin{array}{l}-10.2267 \\
(-2.01) * *\end{array}$ & $\begin{array}{l}0.8390 \\
(0.19)\end{array}$ & $\begin{array}{l}0.1985 \\
(0.09)\end{array}$ \\
\hline GDP per capita & 132.103 & 65.6715 & 71.7852 & 55.1966 \\
\hline $\begin{array}{l}\text { Electricity consumption } \\
\text { Financial structure }\end{array}$ & $\begin{array}{l}(2.59) * * \\
-3.559 \\
(-0.09)\end{array}$ & $\begin{array}{l}(1.70) * \\
-21.6754 \\
(-0.60)\end{array}$ & $\begin{array}{l}(1.73) * \\
-27.4488 \\
(-0.91)\end{array}$ & $\begin{array}{l}(2.74) * * \\
-33.8408 \\
(-2.10)\end{array}$ \\
\hline Financial development & $\begin{array}{l}-10.965 \\
(-2.16) * *\end{array}$ & $\begin{array}{l}-4.2394 \\
(-0.85)\end{array}$ & $\begin{array}{l}1.7500 \\
(0.23)\end{array}$ & $\begin{array}{l}-3.4405 \\
(-1.67) *\end{array}$ \\
\hline Advanced dummy & $\begin{array}{l}0.387 \\
(5.33) * * *\end{array}$ & $\begin{array}{l}0.1382 \\
(1.97) * *\end{array}$ & $\begin{array}{l}0.0506 \\
(0.76)\end{array}$ & $\begin{array}{l}0.0894 \\
(3.04) * * *\end{array}$ \\
\hline Advanced structure & $\begin{array}{l}0.079 \\
(1.52)\end{array}$ & $\begin{array}{l}0.1617 \\
(0.10)\end{array}$ & $\begin{array}{l}0.2369 \\
(1.79) *\end{array}$ & $\begin{array}{l}2.1574 \\
(3.03) * * *\end{array}$ \\
\hline Time dummies & $\begin{array}{l}32.219 \\
(3.87) * * * \\
12.7487 \\
(6.06) * * *\end{array}$ & $\begin{array}{l}22.6845 \\
(2.91) * * * \\
16.6054 \\
(8.23) * * *\end{array}$ & $\begin{array}{l}8.3707 \\
(1.09) \\
5.5932 \\
(3.37) * * *\end{array}$ & $\begin{array}{l}1.2318 \\
(0.37) \\
0.4115 \\
(0.48)\end{array}$ \\
\hline Observations & 527 & 526 & 446 & 500 \\
\hline Sargan test & $\begin{array}{l}\text { Chi2(65)=388.33 } \\
{[0.00] * * *}\end{array}$ & $\begin{array}{l}\text { Chi2(65) }=352.95 \\
{[0.0000] * * *}\end{array}$ & $\begin{array}{l}\text { Chi2(65) }=226.87 \\
{[0.0000] * * *}\end{array}$ & $\begin{array}{l}\text { Chi2(65) }=273.84 \\
{[0.0000] * * *}\end{array}$ \\
\hline $\begin{array}{l}1^{\text {st }} \text { order residual } \\
\text { autocorrelation }\end{array}$ & $\begin{array}{l}\mathrm{Z}=-6.28 \\
{[0.000] * * *}\end{array}$ & $\begin{array}{l}Z=-5.95 \\
{[0.000)}\end{array}$ & $\begin{array}{l}Z=-4.74 \\
{[0.000]}\end{array}$ & $\begin{array}{l}Z=-7.37 \\
{[0.0000] * * *}\end{array}$ \\
\hline $\begin{array}{l}2^{\text {nd }} \text { order residual } \\
\text { autocorrelation }\end{array}$ & $\begin{array}{l}Z=-0.59 \\
{[0.533]}\end{array}$ & $\begin{array}{l}Z=-1.00 \\
{[0.340]}\end{array}$ & $\begin{array}{l}-1.27 \\
{[0.2053]}\end{array}$ & $\begin{array}{l}Z=-0.60 \\
{[0.5452]}\end{array}$ \\
\hline
\end{tabular}

Note: All regressions include time dummies. $T$ values in parenthesis and $p$ values in squared bracket. ***, **, and $*$ implies significant at 1, 5 and 10 percent significant levels respectively. 
In sum, the empirical evidence presented in this paper does not provide any significant and robust role for financial structure in explaining cross-country diffusion of ICT even in advanced countries.

\section{CONCLUDING REMARKS}

This paper has examined the role of financial development and financial structure in explaining cross-country diffusion of information communication technology for a group of developing and advanced countries. There are four important findings.

- $\quad$ First, income influences ICT infrastructure because it relates to higher use of fixed and mobile phones, Internet, and personal computers.

- $\quad$ Second, there is a positive impact of government trade policies on ICT. Openness is associated with the adoption and adaptation of technology. These findings are, in general, consistent with the results of other studies.

- $\quad$ Third, financial development is associated with higher use of ICTs. In particular, the overall level of development of stock markets and banks tends to foster ICT development.

- $\quad$ Last, the structure of a country's capital market does not appear to have any significant relationship with the level of ICT development.

We find that, in a broad sample encompassing developed and developing countries, important policy variables that have generated a lot attention (such as the cost of telecommunication access) do not show up as statistically or economically important in explaining the Internet divide. This result should not be taken as implying that pricing policies are not relevant. Rather, it suggests that such issues are probably overshadowed by economic and financial factors in samples with wide variation of Internet penetration rates. It is important to emphasize that pricing policies are found to be important in explaining fixed and mobile telephone usage.

The conclusions of the paper highlight the role of financial development in the market for knowledge-based products, and consistent with the theoretical propositions of Saint-Paul (1992). This result provides a strong motivation for promoting the development of the financial system in emerging markets. On the other hand, the finding that financial development is an important determinant of ICT diffusion implies that countries with underdeveloped financial markets may sink even further in the information-poor and noncommunicating side of the digital divide. 


\section{References}

Adriani, Fabrizio, and Leonardo Becchetti, 2003, “Does the Digital Divide Matter? The Role of Information and Communication Technology in Cross Country Level and Growth Estimates,” CEIS Working Paper No. 4, Centre for International Studies on Economic Growth (Rome: Center of International Studies on Economic Growth).

Allen, Franklin, and Douglas Gale, 1999b, "Diversity of Opinion and Financing of New Technologies,” Journal of Financial Intermediation, Vol. 8, pp. 68-89.

—_, 2000, Comparing Financial Systems (Cambridge, MA: MIT Press).

Arellano, Manuel, and Stephen Bond, 1991, "Some Tests of Specification for Panel Data: Monte Carlo Evidence and an Application to Employment Equations," Review of Economic Studies, Vol. 58, No. 2, pp. 277-97.

Baliamounte-Lutz, Mina, 2003, “An Analysis of the Determinants and Effects of ICT Diffusion in Developing Countries,” Information Technology for Development, Vol. 10, pp. 15169.

Beilock, Richard, and Daniela V. Dimitrova, 2003, “An Exploratory Model of Inter-Country Internet Diffusion,” Telecommunication Policy, Vol. 27, pp. 237-52.

Black, Bernard S., and Ronald J. Gilson, 1998, "Venture Capital and the Structure of Capital Markets: Banks versus Stock Markets,” Journal of Financial Economics, Vol. 47, No. 3, pp. 243-77.

Chow, Gregory C., 1983, Econometrics (New York: McGraw Hill).

Chinn, Menzie D., and Robert W. Fairlie, 2004, “The Determinants of the Global Digital Divide: A Cross-Country Analysis of Computer and Internet Penetration,” eScholarship Repository No. 562, University of California, Santa Cruz.

Dasgupta, Susmita, Somik Lall, and David Wheeler, 2001, "Policy Reform, Economic Growth, and the Digital Divide: An Econometric Analysis,” World Bank Working Paper No. 2567 (Washington DC: World Bank).

Demirguc-Kunt, Asli, and Ross Levine, 1999, "Bank-Based and Market-Based Financial Systems: Cross Country Comparisions,” World Bank Working Paper, (Washington DC: The World Bank)

Dewan, Sanjeev, Dale Ganley, and Kenneth L. Kraemer, 2004, “Across the Digital Divide: A Cross Country Analysis of the Determinants of IT Penetration,” PCIC Working Paper (Irvine: University of California).

Dewan, Sanjeev, and Kenneth L. Kraemer, 2000, “Information Technology and Productivity: Evidence from Country Level Data,” Management Science, Vol. 46, No.4, pp. 548-62. 
Edwards, Jeremy, and Klaus Fischer, 1994, Banks, Finance and Investment in Germany (Cambridge: Cambridge University Press).

Gilson, Ronald, 1996, “Corporate Governance and Economic Efficiency,” Washington University Law Quarterly, Vol. 74, pp. 327-45.

_ 1997, “The Legal Infrastructure of High-Technology Industrial Districts: Silicon Valley and Covenants Not to Compete," (unpublished; Stanford, CA: Stanford Law School).

Goldsmith, Raymond, W. 1969, Financial Structure and Development (New Haven: Yale University Press)

Hicks, John R., 1969, A Theory of Economic History (Oxford: Clarendon Press).

International Communications Union, 2005, International Telecommunication Indicators, available at: http://www.itu.int/itu-d/ict/statistics.

Jorgenson, Dale W., 2001, “Information Technology and the U.S. Economy,” American Economic Review, Vol. 91, pp. 1-32.

Jussawalla, Mehero, 1999, “The Impact of IT Convergence on Development in the AsiaPacific,” Telecomunnications Policy, Vol. 23, pp. 217-34.

Kiiki, Sampsa and Matti Pohjola, 2002, “Cross Country Diffusion of the Internet,” Information Economics and Policy, Vol. 14, pp. 297-310.

Norris, Pippa, 2000, “The Global Divide: Information Poverty and Internet Access Worldwide,” Presented at International Political Science Congress, Quebec City.

Pohjola, Matti, 2003,“The Adoption and Diffusion of ICT across Countries: Patterns and Determinants,” The New Economy Handbook (San Diego: Elsevier-Academic Press).

Quah, Danny, 1999, “Technology and Growth: The Weightless Economy in Economic Development, London School of Economics Discussion Paper, No. 17. (London: London School of Economics)

Quibria, MG., Ahmed, N. Shamsun, Ted Tschang, and Mari-Len Reyes-Macasaquit (2003), "Digital Divide: Determinants and Policies with Special Reference to Asia,” Journal of Asian Economics, Vol. 13, pp. 811-25.

Robinson, Joan, 1952, The Rate of Interest and Other Essays ( London: Macmillan).

Saint-Paul, Gilles, 1992, “Technological Choice, Financial Markets and Economic Development,” European Economic Review, Vol. 36, pp. 763-81.

Singh, Ajit, 1997, “Financial Liberalization, Stock Markets, and Economic Development,” The Economic Journal, Vol. 107, pp. 771-82. 
Singh, Ajit. and Rahul Dhumale, 2000, “Globalization, Technology, and Income Inequality: A Critical Analysis,” unpublished manuscript, Cambridge University.

Singh, Ajit., Alaka Singh, and Bruce Weisse, 2001, "Information Technology, Venture Capital and the Stock Market,” a background paper for the International Labour Organization's World Employment Report, 2000-2001.

Singh, Ajit, Jack Glen, Alaka Singh, Bruce Weisse, and Ann Zammit, 2005, "Shareholder Wealth Maximization, Stock Market and New Technology: Should the U.S. Corporate Model Be the Universal Standard? Center for Business Research Working Paper No. 325 (Cambridge, U.K.: Cambridge University).

Stulz, Rene, .M., 2001, “Does Financial Structure Matter for Economic Growth? A Corporate Finance Perspective” in Demirguç-Kunt, Aslí, and Ross Levine, eds., Financial Structure and Economic Growth: A Cross Country Comparison of Banks, Markets, and Development (Cambridge, MA: MIT Press).

Wallsten, Scott, 2003, "Regulation and Internet Use in Developing Countries,” AEI-Brookings Joint Center for Regulatory Studies Related Publication, No. 03-8, (Washington, DC: AEI and Brookings Institutions).

Wong, Poh-Kam, . 2002, “ICT Production and Diffusion in Asia: Digital Dividends or Digital Divide?” Information Economics and Policy, Vol. 14 (2), pp. 167-87. 